\title{
Development of a fed-batch process for a recombinant Pichia pastoris $\Delta$ och1 strain expressing a plant peroxidase
}

\author{
Christoph Gmeiner ${ }^{1}$, Amirhossein Saadati ${ }^{1}$, Daniel Maresch², Stanimira Krasteva' ${ }^{1}$, Manuela Frank'
} Friedrich Altmann ${ }^{2}$, Christoph Herwig ${ }^{1}$ and Oliver Spadiut ${ }^{1 *}$

\begin{abstract}
Pichia pastoris is a prominent host for recombinant protein production, amongst other things due to its capability of glycosylation. However, N-linked glycans on recombinant proteins get hypermannosylated, causing problems in subsequent unit operations and medical applications. Hypermannosylation is triggered by an a-1,6-mannosyltransferase called $\mathrm{OCH} 1$. In a recent study, we knocked out $\mathrm{OCH} 1$ in a recombinant $P$. pastoris $\mathrm{CBS} 7435 \mathrm{Mut}^{\mathrm{S}}$ strain ( $\Delta$ och 1 ) expressing the biopharmaceutically relevant enzyme horseradish peroxidase. We characterized the strain in the controlled environment of a bioreactor in dynamic batch cultivations and identified the strain to be physiologically impaired. We faced cell cluster formation, cell lysis and uncontrollable foam formation.

In the present study, we investigated the effects of the 3 process parameters temperature, $\mathrm{pH}$ and dissolved oxygen concentration on 1) cell physiology, 2) cell morphology, 3) cell lysis, 4) productivity and 5) product purity of the recombinant $\Delta$ och 1 strain in a multivariate manner. Cultivation at $30^{\circ} \mathrm{C}$ resulted in low specific methanol uptake during adaptation and the risk of methanol accumulation during cultivation. Cell cluster formation was a function of the C-source rather than process parameters and went along with cell lysis. In terms of productivity and product purity a temperature of $20^{\circ} \mathrm{C}$ was highly beneficial. In summary, we determined cultivation conditions for a recombinant P. pastoris $\Delta$ och1 strain allowing high productivity and product purity.
\end{abstract}

Keywords: Pichia pastoris, Glycosylation, $\mathrm{OCH1}$, Horseradish peroxidase, Bioreactor cultivation, Fed-batch, Design of Experiments

\section{Introduction}

The methylotrophic yeast Pichia pastoris is an attractive host for the recombinant production of proteins and biopharmaceuticals (e.g. [1-3]). It can grow on inexpensive media to high cell densities [1], numerous molecular manipulation tools are available [4] and high production titers are possible $[5,6]$. Due to the capacity of performing posttranslational modifications, like glycosylation, P. pastoris is attractive for the production of eukaryotic proteins (e.g. [3,7-10]). However, the glycosylation capacity of this yeast also is a curse: native glycosyltransferases recognize the aminoacid motif N-X-S/T and link N-glycans

\footnotetext{
* Correspondence: oliver.spadiut@tuwien.ac.at

'Vienna University of Technology, Institute of Chemical Engineering, Research Area Biochemical Engineering, Gumpendorfer Strasse 1a, 1060 Vienna, Austria

Full list of author information is available at the end of the article
}

to the asparagine [11,12]. In contrast to mammalians, however, no trimming reactions of the attached glycans happen, but the glycans are further extended, a phenomenon known as hyperglycosylation [13]. The first reaction of this cascade is catalyzed by an $\alpha-1,6$-mannosyltransferase (OCH1) localized in the Golgi apparatus $[14,15]$. Hyperglycosylation describes a huge problem since not only the physico-chemical properties of the target protein get masked leading to difficulties in the downstream process [16], but also yeast derived glycans are not compatible with the human organism and can cause immunogenic reactions [17]. Consequently, there have been numerous attempts to manipulate the native glycosylation machinery of $P$. pastoris (e.g. [18-22]). In a recent study, we deleted $\mathrm{OCH} 1$ in a recombinant $P$. pastoris strain $(\Delta o c h 1)$ and physiologically characterized the strain in the controlled environment of a bioreactor [23]. We purified the recombinant product horseradish 
peroxidase (EC 1.11.1.7; HRP; e.g. [24]) and analyzed catalytic constants, thermal stability as well as protein glycosylation. Although the $\Delta o c h 1$ strain produced the recombinant protein with shorter glycans of considerably increased homogeneity, the strain was physiologically impaired and thus hard to cultivate. We faced cell cluster formation, cell lysis and uncontrollable foam formation $[25,26]$.

In the present study, we investigated the effects of the 3 process parameters temperature, $\mathrm{pH}$ and dissolved oxygen concentration $\left(\mathrm{dO}_{2}\right)$ on 1) cell physiology, 2) cell morphology, 3) cell lysis, 4) productivity and 5) product purity in a multivariate manner to identify fed-batch operating conditions for the recombinant $\Delta o c h 1$ strain which give both high productivity and product purity, and hamper methanol accumulation as well as cell lysis and consequent foam formation.

\section{Material and methods}

\section{Microorganism}

A P. pastoris CBS7435 $\mathrm{Mut}^{\mathrm{S}} \Delta$ och1 strain carrying the gene coding for the HRP isoenzyme A2A was provided by Prof. Anton Glieder (University of Technology, Graz, Austria). Strain generation and isoenzyme characteristics were described previously [23,27]. A recombinant $P$. pastoris $\mathrm{CBS7435} \mathrm{Mut}^{\mathrm{S}}$ strain with intact $\mathrm{OCH} 1$ expressing HRP A2A, hereafter called wildtype OCH1 strain, was included as reference.

\section{Design of experiments}

A $2^{3}$-level full factorial screening approach with 2 centre points was set up with the program MODDE (Umetrics, Sweden) to explore the influence of the 3 factors temperature $\left(20-30^{\circ} \mathrm{C}\right), \mathrm{pH}(5.0-7.0)$ and $\mathrm{dO}_{2}(10-30 \%)$ as well as their linear interactions on different response parameters resulting in a total of 10 fed-batch cultivations (Table 1). We chose the limits for temperature

\begin{tabular}{|c|c|c|c|c|}
\hline Cultivation & Run order & Temperature $\left[{ }^{\circ} \mathrm{C}\right]$ & $\mathrm{pH}$ & $\mathrm{dO}_{2}[\%]$ \\
\hline DoE1 & 9 & 20 & 5 & 30 \\
\hline DoE2 & 1 & 20 & 5 & 10 \\
\hline DoE3 & 8 & 30 & 5 & 30 \\
\hline DoE4 & 2 & 30 & 7 & 30 \\
\hline DoE5 & 6 & 30 & 7 & 10 \\
\hline DoE6 & 3 & 25 & 6 & 20 \\
\hline DoE7 & 10 & 20 & 7 & 10 \\
\hline DoE8 & 4 & 20 & 7 & 30 \\
\hline DoE9 & 7 & 25 & 6 & 20 \\
\hline DoE10 & 5 & 30 & 5 & 10 \\
\hline
\end{tabular}

with $20-30^{\circ} \mathrm{C}$, since this temperature range is reported for yeasts (e.g. [28-31]). For $\mathrm{pH}$ we investigated values between pH 5.0 and 7.0 (e.g. [32]), since P. pastoris does not grow well at more acidic or alkaline conditions and also HRP exhibits high stability in this $\mathrm{pH}$ range [16]. Finally, we investigated $\mathrm{dO}_{2}$ levels between $10-30 \%$, which is again a range which had been used for $P$. pastoris before (e.g. [30,32,33]).

We analyzed the effects of the 3 factors on 1) strain physiology (specific substrate uptake rate during methanol adaptation $\left(\mathrm{q}_{\mathrm{s}} \mathrm{MeOH}\right.$ adapt $)$, methanol accumulation during fed-batch $\left(\mathrm{MeOH}_{\text {accum }}\right)$, biomass yield $\left(\mathrm{Y}_{\mathrm{X} / \mathrm{S}}\right)$ and $\mathrm{CO}_{2}$ yield $\left.\left(\mathrm{Y}_{\mathrm{CO} 2 / \mathrm{S}}\right)\right)$, 2) strain morphology (cell size distribution), 3) cell lysis (extracellular DNA content), 4) productivity (space-time-yield STY $\left[\mathrm{U} \cdot \mathrm{L}^{-1} \cdot \mathrm{h}^{-1}\right]$, specific productivity $\mathrm{q}_{\mathrm{p}}$ $\left[\mathrm{U} \cdot \mathrm{g}^{-1} \cdot \mathrm{h}^{-1}\right]$ ) and 5) product purity (defined as the amount of target protein in relation to the amount of total extracellular protein $\left.\left[\mathrm{U} \cdot \mathrm{mg}^{-1}\right]\right)$.

\section{Bioreactor cultivations}

The $P$. pastoris $\Delta o c h 1$ strain expressing HRP isoenzyme A2A was cultivated in the controlled environment of a bioreactor. Batch and fed-batch phase were performed on glycerol, followed by a methanol adaptation pulse. Afterwards, a methanol fed-batch with a controlled feed rate corresponding to a certain specific substrate uptake rate of methanol $\left(\mathrm{q}_{\mathrm{s} \mathrm{MeOH}}\right)$ was done.

\section{Culture media}

Precultures were done in yeast nitrogen base medium (YNBM; $0.1 \mathrm{M}$ potassium phosphate buffer $\mathrm{pH}$ 6.0, 3.4 g. $\mathrm{L}^{-1} \mathrm{YNB}$ w/o amino acids and ammonia sulfate, $10 \mathrm{~g} \cdot \mathrm{L}^{-1}$ $\left(\mathrm{NH}_{4}\right)_{2} \mathrm{SO}_{4}, 400 \mathrm{mg} \cdot \mathrm{L}^{-1}$ biotin, $20 \mathrm{~g} \cdot \mathrm{L}^{-1}$ glucose). Zeocine was added at a concentration of $100 \mu \mathrm{g} \cdot \mathrm{L}^{-1}$.

Batch and fed-batch cultivations were performed in 2fold concentrated basal salt medium (BSM; $21.6 \mathrm{~mL} \cdot \mathrm{L}^{-1}$ $85 \%$ phosphoric acid, $0.36 \mathrm{~g} \cdot \mathrm{L}^{-1} \mathrm{CaSO}_{4} \cdot 2 \mathrm{H}_{2} \mathrm{O}, 27.24 \mathrm{~g} \cdot \mathrm{L}^{-1}$ $\mathrm{K}_{2} \mathrm{SO}_{4}, 4.48 \mathrm{~g} \cdot \mathrm{L}^{-1} \quad \mathrm{MgSO}_{4} \cdot 7 \mathrm{H}_{2} \mathrm{O}, 8.26 \mathrm{~g} \cdot \mathrm{L}^{-1} \mathrm{KOH}$, $0.3 \mathrm{~mL} \cdot \mathrm{L}^{-1}$ Antifoam Struktol J650, $4.35 \mathrm{~mL} \cdot \mathrm{L}^{-1} \mathrm{PTM} 1$, $\mathrm{NH}_{4} \mathrm{OH}$ as $\mathrm{N}$-source). Trace element solution (PTM1) was made of $6.0 \mathrm{~g} \cdot \mathrm{L}^{-1} \mathrm{CuSO}_{4} \cdot 5 \mathrm{H}_{2} \mathrm{O}, 0.08 \mathrm{~g} \cdot \mathrm{L}^{-1} \mathrm{NaI}$, $3.0 \mathrm{~g} \cdot \mathrm{L}^{-1} \quad \mathrm{MnSO}_{4} \cdot \mathrm{H}_{2} \mathrm{O}, 0.2 \mathrm{~g} \cdot \mathrm{L}^{-1} \mathrm{Na}_{2} \mathrm{MoO}_{4} \cdot 2 \mathrm{H}_{2} \mathrm{O}$, $0.02 \mathrm{~g} \cdot \mathrm{L}^{-1} \mathrm{H}_{3} \mathrm{BO}_{3}, 0.5 \mathrm{~g} \cdot \mathrm{L}^{-1} \mathrm{CoCl}_{2}, 20.0 \mathrm{~g} \cdot \mathrm{L}^{-1} \mathrm{ZnCl}_{2}$, $65.0 \mathrm{~g} \cdot \mathrm{L}^{-1} \quad \mathrm{FeSO}_{4} \cdot 7 \mathrm{H}_{2} \mathrm{O}, 0.2 \mathrm{~g} \cdot \mathrm{L}^{-1}$ biotin, $5 \mathrm{~mL} \cdot \mathrm{L}^{-1}$ $\mathrm{H}_{2} \mathrm{SO}_{4}$. Induction was carried out in presence of the heme-precursor $\Delta$-aminolevulinic acid at a final concentration of $1 \mathrm{mM}$. The concentration of the base $\mathrm{NH}_{4} \mathrm{OH}$ was determined by titration with $0.25 \mathrm{M}$ potassium hydrogen phthalate.

\section{Preculture}

Frozen stocks $\left(-80^{\circ} \mathrm{C}\right)$ were cultivated in $100 \mathrm{~mL}$ YNBM-Zeocine in $1,000 \mathrm{~mL}$ shake flasks at $30^{\circ} \mathrm{C}$ and $230 \mathrm{rpm}$ for $48 \mathrm{~h}$. Then, the preculture was transferred 
aseptically to the culture vessel. The inoculum volume was $10 \%$ of the final starting volume.

\section{Batch and non-induced fed-batch}

Batch cultivations were carried out in a $3 \mathrm{~L}$ working volume glass bioreactor (Infors, Switzerland). Basal salt medium was sterilized in the bioreactor and $\mathrm{pH}$ was adjusted to $\mathrm{pH}$ 6.0, which corresponds to the centre point of the subsequent DoE, by concentrated $\mathrm{NH}_{4} \mathrm{OH}$ solution after autoclaving. Sterile filtered trace elements were transferred to the reactor. Dissolved oxygen $\left(\mathrm{dO}_{2}\right)$ was measured with a sterilizable fluorescence dissolved oxygen electrode (Visiferm DO425, Hamilton, Germany). The $\mathrm{pH}$ was measured with a sterilizable electrode (Easyferm ${ }^{\mathrm{Tw}}$, Hamilton, Switzerland) and maintained constant with a PID controller using $\mathrm{NH}_{4} \mathrm{OH}$ solution ( 2 to $3 \mathrm{M}$ ). Base consumption was determined gravimetrically. Cultivation temperature was set to $30^{\circ} \mathrm{C}$ and agitation was fixed to $900 \mathrm{rpm}$. The culture was aerated with $1.0 \mathrm{vvm}$ dried air and off-gas of the culture was measured by using an infrared cell for $\mathrm{CO}_{2}$ and a paramagnetic cell for $\mathrm{O}_{2}$ concentration (Servomax, Switzerland). Temperature, $\mathrm{pH}, \mathrm{dO}_{2}$, agitation as well as $\mathrm{CO}_{2}$ and $\mathrm{O}_{2}$ in the off-gas were measured online and logged in a process information management system (PIMS; Lucullus, Biospectra, Switzerland). After the complete consumption of the substrate glycerol, indicated by an increase of $\mathrm{dO}_{2}$ and a drop in off-gas activity, an exponential fed-batch phase on glycerol with a specific growth rate of $\mu=0.08 \mathrm{~h}^{-1}$ was performed. Based on the amount of glycerol used in the batch and the biomass yield on glycerol of $Y_{X / S}=0.47 \mathrm{~g} \cdot \mathrm{g}^{-1}$, we calculated the biomass concentration after the batch phase. The feed rate was then determined by equations 1 and 2 and controlled by the PIMS. The fed-batch on glycerol was stopped when the reactor volume reached $2.2 \mathrm{~L}$.

$$
\begin{aligned}
& \boldsymbol{F}_{0}=\boldsymbol{X} \cdot \boldsymbol{V} \cdot \mu \frac{\boldsymbol{\delta}_{\text {Feed }}}{\boldsymbol{Y}_{\frac{X}{S}} \cdot \boldsymbol{c}_{\text {Feed }}} \\
& \boldsymbol{F}=\boldsymbol{F}_{0} \cdot \boldsymbol{e}^{(\mu \cdot \boldsymbol{t})}
\end{aligned}
$$

$\mathrm{F}_{0}=$ initial feed rate $\left[\mathrm{g} \cdot \mathrm{h}^{-1}\right] ; \mathrm{X}=$ calculated biomass concentration $\left[\mathrm{g} \cdot \mathrm{L}^{-1}\right] ; \mathrm{V}=$ volume in the bioreactor $[\mathrm{L}]$; $\mu=$ specific growth rate $\left[\mathrm{h}^{-1}\right] ; \delta_{\text {Feed }}=$ density glycerol feed $\left[\mathrm{g} \cdot \mathrm{L}^{-1}\right] ; \mathrm{Y}_{\mathrm{X} / \mathrm{S}}=$ biomass yield; $\mathrm{c}_{\mathrm{Feed}}=$ concentration feed $\left[\mathrm{g} \cdot \mathrm{L}^{-1}\right] ; \mathrm{F}=$ calculated feed rate $\left[\mathrm{g} \cdot \mathrm{h}^{-1}\right]$; e, Euler constant; $\mathrm{t}=$ time $[\mathrm{h}]$

Before fed-batch experiments, a single batch cultivation with dynamic methanol pulses was performed to determine $\mathrm{q}_{\mathrm{smax} \mathrm{MeOH}}$ at $20^{\circ} \mathrm{C}, 25^{\circ} \mathrm{C}$ and $30^{\circ} \mathrm{C}$ [25,26,34]. After complete consumption of glycerol, a methanol adaptation pulse (supplemented with $12 \mathrm{~mL} \cdot \mathrm{L}^{-1}$ PTM1) of a final concentration of $0.5 \%(\mathrm{v} / \mathrm{v})$ was conducted. Following pulses were performed with $1 \%$ methanol $(\mathrm{v} / \mathrm{v})$. At least 3 consecutive methanol pulses were analyzed at each temperature. For each pulse, at least two samples were taken to determine the concentrations of substrate and product, as well as dry cell weight to calculate specific rates and yields. Furthermore, biomass was used to determine the correlation between dry cell weight (DCW) and optical density at $600 \mathrm{~nm}\left(\mathrm{OD}_{600}\right)$. The $\mathrm{DCW}$ of diluted samples (1:2, 1:4, 1:6, 1:8 and 1:10) was plotted against the corresponding $\mathrm{OD}_{600}$ values (Genesys 20; Thermo Scientific, Austria) resulting in a so-called $\alpha$-factor, which was used for biomass calculation in subsequent fed-batch cultivations (equation 3).

$$
\mathbf{X}=\mathbf{O D}_{600} \cdot \mathbf{\alpha}
$$

$\mathrm{X}=$ calculated biomass $\left[\mathrm{g} \cdot \mathrm{L}^{-1}\right] ; \mathrm{OD}_{600}=$ optical density at $600 \mathrm{~nm} ; \alpha=$ correlation factor between DCW and $\mathrm{OD}_{600}$ value.

\section{Induction}

After glycerol depletion, temperature, $\mathrm{pH}$ and $\mathrm{dO}_{2}$ were changed according to Table 1 . To control $\mathrm{dO}_{2}$, a PID controller was implemented regulating $\mathrm{dO}_{2}$ by aeration and not by stirrer speed. Thus, potential influences on cell cluster formation were omitted. After parameters reached the target values, a $0.5 \%(\mathrm{v} / \mathrm{v})$ methanol adaptation pulse was applied. Concomitantly, the heme-precursor $\Delta$-aminolevulinic acid was aseptically added at a final concentration of $1 \mathrm{mM}$. When the culture was adapted to methanol, indicated by an increase of $\mathrm{dO}_{2}$ and a drop in off-gas activity, a methanol fed-batch at a feed rate corresponding to a $\mathrm{q}_{\mathrm{s}} \mathrm{MeOH}$ of $0.2 \mathrm{mmol} \cdot \mathrm{g}^{-1} \cdot \mathrm{h}^{-1}$ was performed for around 100 hours. The feed rate was determined by equation 4 and controlled by the PIMS.

$$
\boldsymbol{F}=\frac{X \cdot V \cdot \mathbf{q}_{\mathbf{s}, \mathrm{MeOH}} \cdot \boldsymbol{\delta}_{\text {Feed }}}{\boldsymbol{c}_{\text {Feed }}}
$$

$\mathrm{F}=$ calculated feed rate $\left[\mathrm{g} \cdot \mathrm{h}^{-1}\right] ; \mathrm{X}=$ biomass concentration calculated from $\mathrm{OD}_{600}\left[\mathrm{~g} \cdot \mathrm{L}^{-1}\right] ; \mathrm{V}=$ volume in the bioreactor $[\mathrm{L}] ; \mathrm{q}_{\mathrm{s} \mathrm{MeOH}}=$ specific methanol uptake rate $\left[\mathrm{mmol} \cdot \mathrm{g}^{-1} \cdot \mathrm{h}^{-1}\right]$; $\mathrm{C}_{\mathrm{Feed}}=$ density of methanol feed $\left[\mathrm{g} \cdot \mathrm{L}^{-1}\right] ; \mathrm{C}_{\mathrm{Feed}}=$ concentration of methanol feed $\left[\mathrm{g} \cdot \mathrm{L}^{-1}\right]$.

\section{Sample analysis}

Dry cell weight was determined by centrifugation of $5 \mathrm{~mL}$ culture broth $\left(5,000 \mathrm{rpm}, 4^{\circ} \mathrm{C}, 10 \mathrm{~min}\right)$ in a laboratory centrifuge (Sigma 4K15, rotor 11156), washing the pellet with $5 \mathrm{~mL}$ deionized water and subsequent drying at $105^{\circ}$ $\mathrm{C}$ to a constant weight in an oven. The enzymatic activity of HRP was measured using an ABTS assay in a CuBiAn $\mathrm{XC}$ enzymatic robot (Innovatis, Germany). Ten $\mu \mathrm{l}$ of sample were mixed with $140 \mu \mathrm{l} 1 \mathrm{mM}$ ABTS solution $(50 \mathrm{mM}$ $\mathrm{KH}_{2} \mathrm{PO}_{4}, \mathrm{pH}$ 6.5). The reaction mixture was incubated at $37^{\circ} \mathrm{C}$ for $5 \mathrm{~min}$ before the reaction was started by the 
addition of $20 \mu \mathrm{l} 0.078 \% \mathrm{H}_{2} \mathrm{O}_{2}(\mathrm{v} / \mathrm{v})$. Changes in absorbance at $415 \mathrm{~nm}$ were measured for 80 seconds and rates were calculated. The standard curve was prepared using a commercially available HRP preparation (Type VI-A, SigmaAldrich, USA) in the range from 0.02 to $2.0 \mathrm{U} \cdot \mathrm{ml}^{-1}$. Protein concentrations were determined at $595 \mathrm{~nm}$ using the Bradford Protein Assay Kit (Bio-Rad Laboratories GmbH, Austria) with bovine serum albumin as standard. Extracellular DNA content was measured by the Nanodrop 1000 device (ThermoScientific, Austria). Concentrations of methanol and potential metabolites were determined in cell-free samples by HPLC (Agilent Technologies, USA) equipped with an ion-exchange column (Supelcogel C-610H Sigma-Aldrich, USA) and a refractive index detector (Agilent Technologies, USA). The mobile phase was $0.1 \% \mathrm{H}_{3} \mathrm{PO}_{4}$ with a constant flow rate of $0.5 \mathrm{~mL} \cdot \mathrm{min}^{-1}$ and the system was run isocratically at $30^{\circ} \mathrm{C}$. All measurements were done in duplicates.

\section{Strain morphology}

Changes in the morphology of the recombinant P. pastoris $\Delta o c h 1$ strain during the bioprocess were monitored by a Malvern Mastersizer 2000, measuring the cell size distribution in all samples. Frozen cell pellets (stored at $-20^{\circ} \mathrm{C}$ ) with a biomass concentration of $10-20 \mathrm{~g} \cdot \mathrm{L}^{-1}$ were thawed and resuspended in $10 \mathrm{~mL}$ deionized water. After dispersing the samples with module Hydro2000S, 6 to 20 drops of cell suspension were dripped into the water tank of the Malvern Mastersizer 2000 until the laser diffraction reached a value between $10-12 \%$. Samples were analyzed between $0-10,000 \mu \mathrm{m}$. Furthermore, all samples were analyzed microscopically using a Zeiss Epifluorescence Axio Observer Z1 deconvolution microscope (Carl Zeiss, Germany) equipped with a LD Plan-Neofluar 63x objective $(+10 x$ ocular) and the LED illumination system Colibri.

\section{Electrophoresis}

Electrophoresis was done with aliquots of supernatants obtained at the end of the cultivation. SDS-PAGE was performed using a $6 \%$ stacking gel and a $12 \%$ separating gel in $1 \mathrm{x}$ Tris-glycine buffer. Gels were run in the vertical electrophoresis Mini-PROTEAN Tetra Cell apparatus (Biorad; Austria) at $150 \mathrm{~V}$ for about 2 h. Gels were stained with Coomassie blue. The protein mass standard used was the PageRuler Prestained Ladder (Fermentas; Austria).

\section{Protein identification and glycopeptide analysis by LC-ESI-MS}

Relevant protein bands were cut out and digested in gel. S-alkylation with iodoacetamide and digestion with sequencing grade modified trypsin (Promega) were performed. The peptide mixture was analysed using a Dionex Ultimate 3000 system directly linked to a QTOF instrument (maXis 4G ETD, Bruker) equipped with the standard ESI source in the positive ion, DDA mode (= switching to MSMS mode for eluting peaks). MSscans were recorded (range: 150-2200 Da) and the 6 highest peaks were selected for fragmentation. Instrument calibration was performed using ESIcalibration mixture (Agilent). For separation of the peptides a Thermo BioBasic C18 separation column (5 $\mu \mathrm{m}$ particle size, $150^{\circ}$ $0.360 \mathrm{~mm}$ ) was used. A gradient from $95 \%$ solvent A and $5 \%$ solvent B (Solvent A: $65 \mathrm{mM}$ ammonium formiate buffer, B: $100 \% \mathrm{ACCN}$ ) to $32 \% \mathrm{~B}$ in 45 min was applied, followed by a 15 min gradient from $32 \%$ B to $75 \%$ B, at a flow rate of $6 \mu \mathrm{L} \cdot \mathrm{min}^{-1}$. The analysis files were converted using Data Analysis 4.0 (Bruker) to XML files, which are suitable to perform MS/MS ion searches with MASCOT (embedded in ProteinScape 3.0, Bruker) for protein identification. Only proteins identified with at least 2 peptides with a protein score higher than 80 were accepted. For searches the SwissProt database was used.

\section{Results and discussion}

In the present study we developed a fed-batch bioprocess for a recombinant $P$. pastoris $\Delta$ och1 strain. We analyzed the effects of 3 process parameters (temperature, $\mathrm{pH}$ and $\mathrm{dO}_{2}$ ) on strain physiology and morphology [23], as well as on productivity and product purity in a multivariate manner.

\section{Dynamic batch cultivation to determine $\mathrm{q}_{\mathrm{s} \text { max } \mathrm{MeOH}}$}

We performed a dynamic batch cultivation with methanol pulses to determine the maximum specific methanol uptake rate $\left(\mathrm{q}_{\mathrm{s} \max \mathrm{MeOH}}\right)$ of the $\Delta o c h 1$ strain at $20^{\circ} \mathrm{C}, 25^{\circ} \mathrm{C}$ and $30^{\circ} \mathrm{C}[25,26]$. The average $\mathrm{q}_{\mathrm{s} \text { max } \mathrm{MeOH}}$ determined for at least 3 consecutive $1 \%(\mathrm{v} / \mathrm{v})$ methanol pulses were $0.43 \mathrm{mmol} \cdot \mathrm{g}^{-1} \cdot \mathrm{h}^{-1}$ at $30^{\circ} \mathrm{C}, 0.74 \mathrm{mmol} \cdot \mathrm{g}^{-1} \cdot \mathrm{h}^{-1}$ at $25^{\circ} \mathrm{C}$ and $0.85 \mathrm{mmol} \cdot \mathrm{g}^{-1} \cdot \mathrm{h}^{-1}$ at $20^{\circ} \mathrm{C}$. Interestingly, $\mathrm{q}_{\mathrm{s}} \max \mathrm{MeOH}$ was strongly temperature dependent. At $20^{\circ} \mathrm{C}$, cells specifically consumed the double amount of methanol per time compared to $30^{\circ} \mathrm{C}$. In previous studies with different microorganisms it was shown that substrate uptake usually declines with lower temperature [35-37]. Thus, we also analyzed a reference strain with intact $\mathrm{OCH} 1$, hereafter referred to as wildtype $\mathrm{OCH} 1$ strain, and indeed observed decreasing $\mathrm{q}_{\mathrm{s}} \mathrm{MeOH}$ with decreasing temperature, namely $1.30 \mathrm{mmol} \cdot \mathrm{g}^{-1} \cdot \mathrm{h}^{-1}$ at $28^{\circ} \mathrm{C}, 1.20 \mathrm{mmol} \cdot \mathrm{g}^{-1} \cdot \mathrm{h}^{-1}$ at $24^{\circ} \mathrm{C}$ and $0.95 \mathrm{mmol} \cdot \mathrm{g}^{-1} \cdot \mathrm{h}^{-1}$ at $20^{\circ} \mathrm{C}$. So far, we do not have a physiological explanation for the opposite behaviour of the recombinant $\Delta o c h 1$ strain. However, since the subsequent $\mathrm{DoE}$ covered a range from $20-30^{\circ} \mathrm{C}$ we designed the fed-batch strategy for the recombinant $\Delta o c h 1$ strain in a way to constantly feed at a rate corresponding to a rather low $\mathrm{q}_{\mathrm{s} \mathrm{MeOH}}=0.2 \mathrm{mmol} \cdot \mathrm{g}^{-1} \cdot \mathrm{h}^{-1}$. This was less than half of the lowest $\mathrm{q}_{\mathrm{s} \max \mathrm{MeOH}}$ determined in the dynamic batch experiment, and thus guaranteed a certain safety margin to avoid methanol accumulation. 


\section{DoE fed-batch cultivations}

We analyzed the effects of the 3 process parameters temperature, $\mathrm{pH}$ and $\mathrm{dO}_{2}$ on 1) strain physiology, 2) strain morphology, 3) cell lysis, 4) productivity and 5) product purity of the recombinant $\Delta o c h 1$ strain. The goal of this multivariate study was to find operating conditions in fedbatch mode which give high productivity and product purity and concomitantly hamper methanol accumulation as well as cell lysis and consequent foam formation. Therefore, we conducted 10 fed-batch experiments in the controlled environment of a bioreactor (Table 1). The batch and the non-induced fed-batch were always performed under the same conditions. Only prior methanol adaptation (i.e. the phase during the Pichia pastoris cells get adapted to methanol) process parameters were changed. The carbon dioxide evolution rate (CER) depicting such a bioprocess is exemplarily shown for cultivation DoE6 in Figure 1.

\section{Effects on strain physiology}

By frequent sampling and subsequent analyses, we physiologically characterized the recombinant $\Delta o c h 1$ strain. The most relevant strain characteristic parameters are summarized in Table 2. The specific glycerol uptake rate in the batch phase ( $\mathrm{q}_{\mathrm{s}}$ Gly batch $)$ was very similar in all cultivations. Only during the induction phase strain characteristic parameters changed. The $\mathrm{q}_{\mathrm{s} \mathrm{MeOH}}$ in the different fed-batches was close to the set value of $0.2 \mathrm{mmol} \cdot \mathrm{g}^{-1} \cdot \mathrm{h}^{-1}$, underlining the validity of the feeding strategy. Furthermore, closing $\mathrm{C}$ balances underline the reliability of the data (Table 2).

Specific substrate uptake rate during methanol adaptation ( $\left.\mathbf{q}_{\mathbf{s} \mathbf{M e O H} \text { adapt }}\right)$ As shown in Figure 2, all 3 factors significantly affected $\mathrm{q}_{\mathrm{s}} \mathrm{MeOH}$ adapt with temperature being the most significant one ( $\mathrm{p}$-values: temperature $=$ $\left.0.0011, \mathrm{pH}=0.0406, \mathrm{dO}_{2}=0.0055\right)$. The summary of fit plot indicated a valid model $(\mathrm{R} 2=0.99, \mathrm{Q} 2=0.90$, Model Validity $=0.95$, Reproducibility $=0.95$ ). At $30^{\circ} \mathrm{C}$ and a $\mathrm{dO}_{2}$ of $30 \%$ the recombinant $\Delta$ och 1 strain only consumed $0.1 \mathrm{mmol} \cdot \mathrm{g}^{-1} \cdot \mathrm{h}^{-1}$, whereas this value was more than doubled at $20^{\circ} \mathrm{C}$. Interestingly, the wildtype $\mathrm{OCH} 1$ strain showed the opposite as at $30^{\circ} \mathrm{C} 0.37 \mathrm{mmol} \cdot \mathrm{g}^{-1} \cdot \mathrm{h}^{-1}$ methanol were consumed but only half was consumed at $20^{\circ} \mathrm{C}\left(0.18 \mathrm{mmol} \cdot \mathrm{g}^{-1} \cdot \mathrm{h}^{-1}\right)$. Summarizing, the lower the temperature, $\mathrm{pH}$ and $\mathrm{dO}_{2}$, the higher was $\mathrm{q}_{\mathrm{s}} \mathrm{MeOH}$ adapt for the recombinant $\Delta o c h 1$ strain (Figure 2).

Methanol accumulation during fed-batch $\left(\mathrm{MeOH}_{\text {accum }}\right)$ During induction the feed rate was regulated to correspond to a constant $\mathrm{q}_{\mathrm{s} \mathrm{MeOH}}=0.2 \mathrm{mmol} \cdot \mathrm{g}^{-1} \cdot \mathrm{h}^{-1}$, which was 2-fold lower than the lowest $\mathrm{q}_{\mathrm{s}} \max \mathrm{MeOH}$ at $30^{\circ} \mathrm{C}$ determined in the dynamic batch experiment. However, methanol still accumulated in cultivations DoE3, DoE4 and DoE10. For DoE3 methanol accumulation set on after around $80 \mathrm{~h}$ and for DoE10 after around $70 \mathrm{~h}$ of induction, whereas for DoE4 methanol accumulated right from the start. In Table 2 methanol concentrations at the end of cultivation are shown. Methanol only accumulated in cultivations at $30^{\circ} \mathrm{C}$ which is in agreement with both the results from the dynamic batch cultivation at $30^{\circ} \mathrm{C}$ where $\mathrm{q}_{\mathrm{s} \text { max }}$ for methanol was the lowest, as well as with the low $\mathrm{q}_{\mathrm{s}} \mathrm{MeOH}$ adapt in fed batch cultivations at $30^{\circ} \mathrm{C}$ (Figure 2). However, we could not identify a significant factor causing this phenomenon since in $\operatorname{DoE} 5\left(30^{\circ} \mathrm{C}, \mathrm{pH} 7.0,10 \% \mathrm{dO}_{2}\right)$ no methanol accumulated (Table 2). Apparently, induction at $30^{\circ} \mathrm{C}$ favours methanol accumulation over time, a phenomenon which was observed before [23]. However,

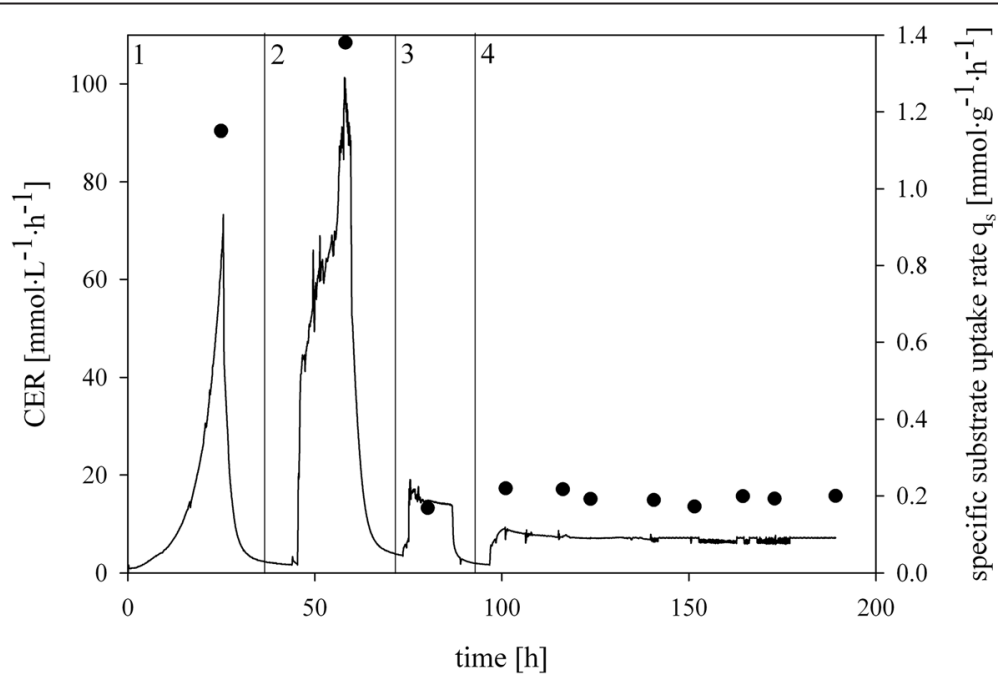

Figure 1 Bioreactor cultivation DoE6. Black line, carbon dioxide evolution rate (CER) depicting metabolic activity; black dot, specific substrate uptake rate $\left(\mathrm{q}_{\mathrm{s}}\right.$ ). All cultivations ran in four phases: 1, batch on glycerol; 2 , non-induced fed-batch on glycerol; 3, methanol adaptation pulse; 4 , fed-batch on methanol. 
Table 2 Strain characteristic parameters of the recombinant $P$. pastoris $\Delta$ och 1 strain induced under different conditions

\begin{tabular}{|c|c|c|c|c|c|c|c|}
\hline Cultivation & $\begin{array}{l}\mathrm{q}_{\mathrm{s} \text { Gly batch }} \\
{\left[\mathrm{mmol} \cdot \mathrm{g}^{-1} \cdot \mathrm{h}^{-1}\right]}\end{array}$ & $\begin{array}{l}\mathrm{q}_{\mathrm{s} \mathrm{MeOH} \text { adapt }} \\
{\left[\mathrm{mmol} \cdot \mathrm{g}^{-1} \cdot \mathrm{h}^{-1}\right]}\end{array}$ & $\begin{array}{l}\mathrm{q}_{\mathrm{s} \text { MeOH fed-batch }} \\
{\left[\mathrm{mmol} \cdot \mathrm{g}^{-1} \cdot \mathrm{h}^{-1}\right]}\end{array}$ & $\begin{array}{l}\mathrm{MeOH}_{\text {accum }} \\
{\left[\mathrm{g} \cdot \mathrm{L}^{-1}\right]}\end{array}$ & $\begin{array}{l}\mathrm{Y}_{\mathrm{CO} / \mathrm{s}} \\
{\left[\mathrm{C}-\mathrm{mol} \cdot \mathrm{C}-\mathrm{mol}^{-1}\right]}\end{array}$ & $\begin{array}{l}\mathrm{Y}_{\mathrm{x} / \mathrm{s}} \\
{\left[\mathrm{C}-\mathrm{mol} \cdot \mathrm{C}-\mathrm{mol}^{-1}\right]}\end{array}$ & C-balance \\
\hline DoE1 & 1.42 & 0.23 & 0.20 & - & 0.80 & 0.21 & 1.01 \\
\hline DoE2 & 1.40 & 0.26 & 0.26 & - & 0.80 & 0.20 & 1.00 \\
\hline DoE3 & 1.38 & 0.08 & 0.18 & 0.68 & 0.82 & 0.23 & 1.05 \\
\hline DoE4 & 1.28 & 0.09 & 0.16 & 4.90 & 0.82 & 0.24 & 1.06 \\
\hline DoE5 & 1.26 & 0.16 & 0.21 & - & 0.83 & 0.26 & 1.09 \\
\hline DoE6 & 1.25 & 0.17 & 0.20 & - & 0.75 & 0.32 & 1.07 \\
\hline DoE7 & 1.39 & 0.16 & 0.20 & - & 0.71 & 0.29 & 1.00 \\
\hline DoE8 & 1.40 & 0.18 & 0.24 & - & 0.69 & 0.33 & 1.02 \\
\hline DoE9 & 1.42 & 0.15 & 0.20 & - & 0.75 & 0.28 & 1.03 \\
\hline DoE10 & 1.42 & 0.16 & 0.21 & 0.20 & 0.80 & 0.27 & 1.07 \\
\hline
\end{tabular}

using the current DoE screening approach based on only 3 factors and the underlying linear regression model, we could not identify significant factors and their interactions causing methanol accumulation. Apparently, a temperature of $30^{\circ} \mathrm{C}$ favours changes in cell physiology and a reduction of methanol uptake over time which is why a lower cultivation temperature of $20^{\circ} \mathrm{C}$ for fed-batch production processes with this $\Delta o c h 1$ strain is highly recommended. In contrast, the wildtype $\mathrm{OCH} 1$ strain can be cultivated at $30^{\circ} \mathrm{C}$ without experiencing changes in methanol uptake.

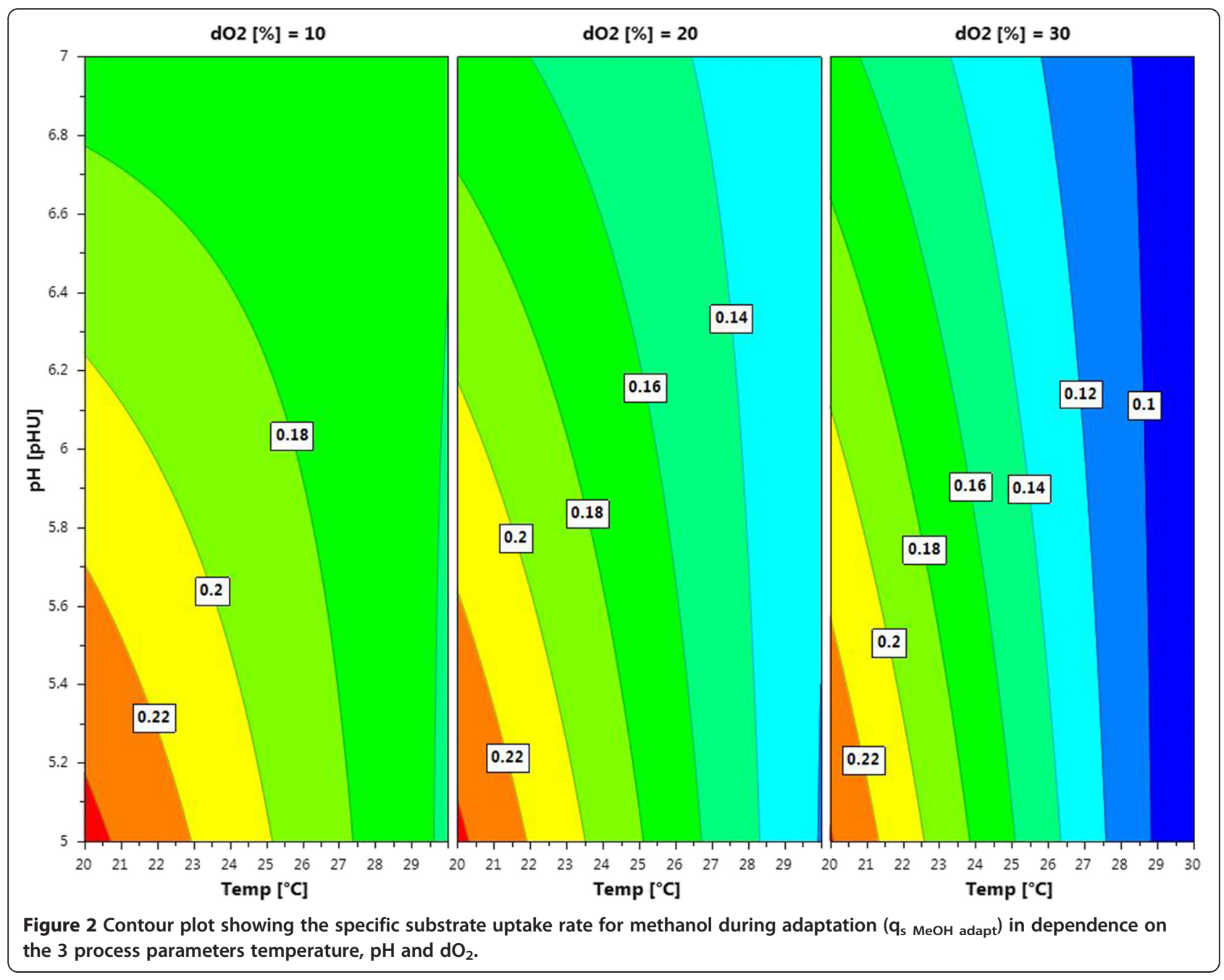


Table 3 Cell-size distribution at different time points of the fed-batch cultivation. Single and budding cells were categorized with a size of $<15 \mu \mathrm{m}$, whereas cell clusters were classified to be $>15 \mu \mathrm{m}$

\begin{tabular}{|c|c|c|c|c|c|c|}
\hline \multirow[t]{2}{*}{ Cultivation } & \multicolumn{2}{|c|}{$\begin{array}{l}\text { Size distribution } \\
\text { after batch [\%] }\end{array}$} & \multicolumn{2}{|c|}{$\begin{array}{l}\text { Size distribution after } \\
\text { non-induced fed-batch [\%] }\end{array}$} & \multicolumn{2}{|c|}{$\begin{array}{l}\text { Size distribution after } \\
\text { induced fed-batch [\%] }\end{array}$} \\
\hline & $<15 \mu \mathrm{m}$ & $>15 \mu \mathrm{m}$ & $<15 \mu \mathrm{m}$ & $>15 \mu \mathrm{m}$ & $<15 \mu \mathrm{m}$ & $>15 \mu \mathrm{m}$ \\
\hline DoE1 & 53.0 & 47.0 & 41.5 & 58.5 & 79.8 & 20.2 \\
\hline DoE2 & 56.8 & 43.2 & 64.8 & 35.2 & 79.9 & 20.1 \\
\hline DoE3 & 54.7 & 45.3 & 60.5 & 39.5 & 64.7 & 35.3 \\
\hline DoE4 & 38.3 & 61.7 & 57.1 & 42.9 & 80.6 & 19.4 \\
\hline DoE5 & 53.8 & 46.2 & 74.8 & 25.2 & 73.3 & 26.7 \\
\hline DoE6 & 55.7 & 44.3 & 70.9 & 29.1 & 81.0 & 19.0 \\
\hline DoE7 & 36.3 & 63.7 & 42.5 & 57.5 & 75.8 & 24.2 \\
\hline DoE8 & 40.8 & 59.2 & 47.0 & 53.0 & 71.0 & 29.0 \\
\hline DoE9 & 49.9 & 50.1 & 69.5 & 30.5 & 90.4 & 9.6 \\
\hline DoE10 & 48.2 & 51.8 & 69.4 & 30.6 & 89.1 & 10.9 \\
\hline average & $48.8 \pm 7.6$ & $51.3 \pm 7.6$ & $59.8 \pm 12.3$ & $40.2 \pm 12.3$ & $78.6 \pm 7.8$ & $21.4 \pm 7.8$ \\
\hline wildtype $\mathrm{OCH} 1$ strain & 87.5 & 12.5 & 87.3 & 12.7 & 86.5 & 13.5 \\
\hline
\end{tabular}

Yields We investigated the influence of the 3 process parameters on both biomass yield $\left(\mathrm{Y}_{\mathrm{X} / \mathrm{S}}\right)$ and $\mathrm{CO}_{2}$ yield $\left(\mathrm{Y}_{\mathrm{CO} / \mathrm{S}}\right)$. However, yields were not affected by varying the 3 process parameters in the design space (Table 2).

\section{Effects on strain morphology}

In a previous study, we had observed cluster formation of the recombinant $\Delta o c h 1$ strain during batch cultivation [23]. To analyze this phenomenon in more detail and monitor it in the different phases of a fed-batch, samples taken during the different fed-batch cultivations were analyzed for cell size distribution in a Malvern Mastersizer. The cell size of an average $P$. pastoris cell lies between 4-6 $\mu \mathrm{m}$ [38]. Of course, budding cells, where two or more daughter cells are still attached to the mother cell, are larger, which is why we categorized all

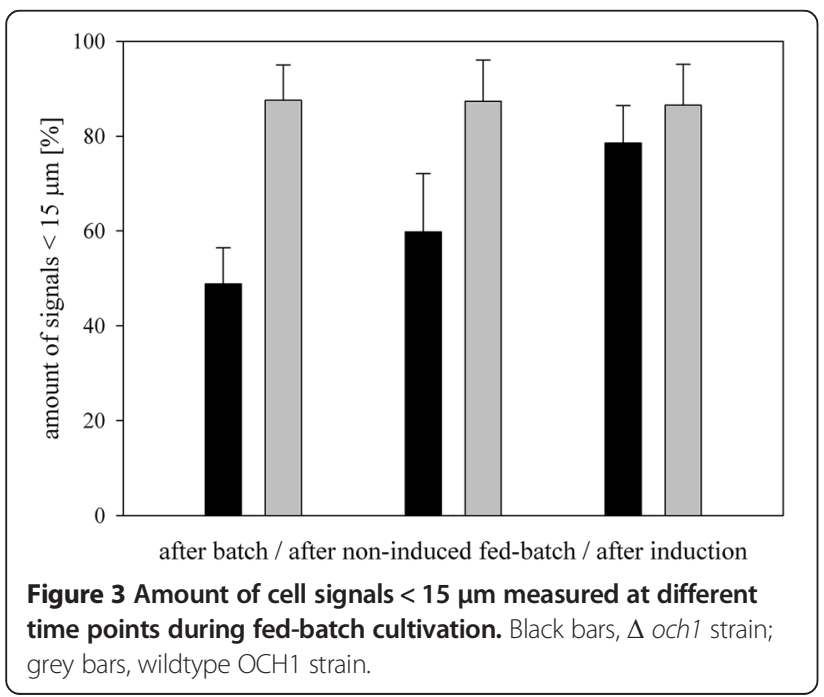

signals $<15 \mu \mathrm{m}$ as single and budding cells and all signals $>15 \mu \mathrm{m}$ as cell clusters. We were especially interested in comparing the samples taken after batch and after non-induced fed-batch, which were both performed on glycerol, with the sample taken at the end of the induction phase on methanol (Table 3). We performed these measurements for all bioreactor cultivations, calculated mean values and standard deviations and compared the results with a wildtype $\mathrm{OCH} 1$ strain which was cultivated in fed-batch mode at $25^{\circ} \mathrm{C}, \mathrm{pH} 6.0$ and $20 \% \mathrm{dO}_{2}$, corresponding to the $\mathrm{DoE}$ centre point (Table 1).

As shown in Table 3, the size distribution of the cells/ cell clusters at the chosen time points of the different DoE cultivations was quite similar. In fact, all 3 factors were not significant for cluster formation. In Figure 3 the average amount of signals $<15 \mu \mathrm{m}$ of the $\Delta$ och 1 strain were compared to the signals of the wildtype OCH1 strain.

Table 4 Extracellular DNA content measured at the end of cultivation

\begin{tabular}{ll}
\hline Cultivation & DNA content $\left[\mathbf{n g} \cdot \boldsymbol{\mu L}^{-1}\right]$ \\
\hline DoE1 & 451 \\
DoE2 & 494 \\
DoE3 & 519 \\
DoE4 & 347 \\
DoE5 & 485 \\
DoE6 & 434 \\
DoE7 & 339 \\
DoE8 & 554 \\
DoE9 & 429 \\
DoE10 & 564 \\
\hline
\end{tabular}



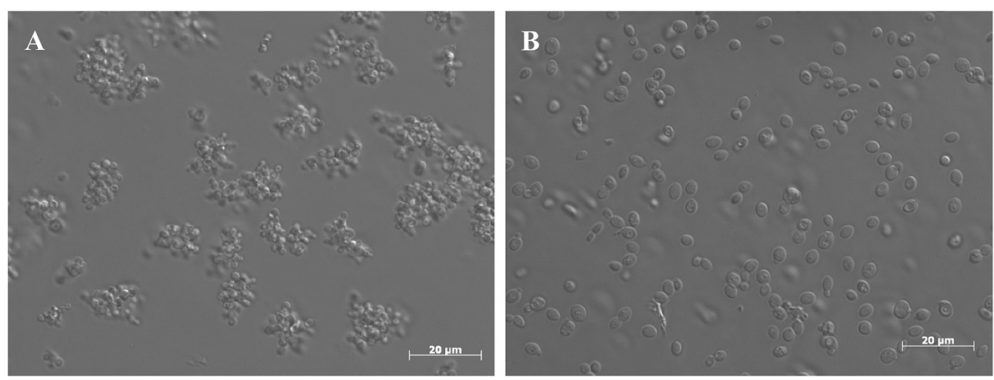

Figure 4 Cell morphology after the fed-batch phase on glycerol of A, the recombinant $\Delta$ och1 strain; B, the wildtype OCH1 strain.

More than $80 \%$ of the signals for the wildtype OCH1 strain were smaller than $15 \mu \mathrm{m}$ during the whole bioprocess (grey bars in Figure 3), whereas the $\Delta$ och1 strain showed different size distributions dependent on the cultivation phase. After the batch on glycerol more than $50 \%$ of the signals indicated cell clusters. These clusters were still prominent after the glycerol fed-batch (40\%). Only after switching the substrate to methanol, the clusters slowly disappeared. After $100 \mathrm{~h}$ of induction, around $80 \%$ of the signals were $<15 \mu \mathrm{m}$, which was similar to the wildtype $\mathrm{OCH} 1$ strain. Cell cluster formation was also followed by light microscopy. In Figure 4, typical $\Delta o c h 1$ cell clusters [23] and budding cells for the control strain after the glycerol fed-batch are shown.

Apparently, cell cluster formation of the recombinant $\Delta o c h 1$ strain was a function of the C-source and not of any of the 3 investigated process parameters. When grown on methanol, cell clusters disappeared over time. However, $\Delta o c h 1$ cells stayed much smaller than wildtype OCH1 cells (Figure 4) which might result from the altered cell wall composition with enhanced chitin deposition [23].

\section{Effects on cell lysis}

Since we had observed intensive foam formation for the recombinant $\Delta o c h 1$ strain before [23], which describes a huge problem for potential scale up, we monitored cell lysis by measuring extracellular DNA content over time. In Table 4 the extracellular DNA contents at the end of the different cultivations are shown. Although the extracellular DNA content constantly increased over time, more than $80 \%$ of the final DNA amount was already present after the fed-batch on glycerol for all cultivations. This strongly indicated that cell lysis went along with cell cluster formation and was not affected by any of the 3 process parameters. We speculate that cells in the center of the clusters get limited in either nutrients or oxygen and thus lyse. Once these clusters disappear due to the switch from glycerol to methanol, cell lysis is diminished. Since none of the 3 process parameters affected lysis, we had to adapt the cultivation strategy during glycerol fedbatch elsewise to avoid extensive foam formation. Initially, agitation was fixed to $900 \mathrm{rpm}$ and the culture was aerated with $1.0 \mathrm{vvm}$ dried air to guarantee $\mathrm{dO}_{2}$ values of $>30 \%$. However, to avoid intensive foam formation, we decreased agitation to $600 \mathrm{rpm}$ and aeration to $0.5 \mathrm{vvm}$, but added pure oxygen. Thus, although cells still lysed during glycerol fed-batch, intensive foam formation was avoided.

\section{Effects on productivity and product purity}

The effects of temperature, $\mathrm{pH}$ and $\mathrm{dO}_{2}$ on $\mathrm{q}_{\mathrm{p}}$ (Additional file 1: Figure S1A), STY (Additional file 1: Figure S1B) and product purity (Additional file 1: Figure S1C) were analyzed and the respective data at the end of cultivation are summarized in Table 5.

The only significant factor for all 3 responses was the temperature, whereas $\mathrm{pH}$ and $\mathrm{dO}_{2}$ had no effect ( $\mathrm{p}$-values for $\mathrm{q}_{\mathrm{p}}$ : temperature $=0.000072, \mathrm{pH}=0.77, \mathrm{dO}_{2}=0.33$; $\mathrm{p}$-values for STY: temperature $=0.000026, \mathrm{pH}=0.37$, $\mathrm{dO}_{2}=0.90 ;$ p-values for specific activity: temperature $=$ $\left.0.000024, \mathrm{pH}=0.49, \mathrm{dO}_{2}=0.45\right)$. The summary of fit plots indicated valid models (for $\mathrm{q}_{\mathrm{p}}$ : $\mathrm{R} 2=0.94, \mathrm{Q} 2=0.88$, Model Validity $=0.77$, Reproducibility $=0.97$; for STY: R2 $=0.95$, $\mathrm{Q} 2=0.81$, Model Validity $=0.55$, Reproducibility $=0.99$; for specific activity: R2 $=0.95, \mathrm{Q} 2=0.93$, Model Validity = 0.87 , Reproducibility $=0.95$ ). To visualize the effects, we plotted the responses versus temperature and $\mathrm{dO}_{2}$ at pH 5.0 (Additional file 1: Figure S1). Summarizing, both highest productivity and product purity were obtained at $20^{\circ} \mathrm{C}$ and a low $\mathrm{dO}_{2}$ at $\mathrm{pH}$ 5.0. Apparently, at lower temperature the recombinant $\Delta o c h 1$ strain secreted more active HRP and less contaminating proteins compared to higher temperatures. This is not only important to increase the total amount of active product over time, but also for the subsequent downstream process. We observed a similar trend for the wildtype $\mathrm{OCH} 1$ strain where $\mathrm{q}_{\mathrm{p}}$ and product purity were both higher at lower temperature: $\left(20^{\circ} \mathrm{C}: \mathrm{q}_{\mathrm{p}}=15 \mathrm{U} \cdot \mathrm{g}^{-1} \cdot \mathrm{h}^{-1}\right.$, specific activity $=95 \mathrm{U} \cdot \mathrm{mg}^{-1}$; $24^{\circ} \mathrm{C}: \mathrm{q}_{\mathrm{p}}=11 \mathrm{U} \cdot \mathrm{g}^{-1} \cdot \mathrm{h}^{-1}$, specific activity $=50 \mathrm{U} \cdot \mathrm{mg}^{-1} ; 28^{\circ} \mathrm{C}$ : $\mathrm{q}_{\mathrm{p}}=6 \mathrm{U} \cdot \mathrm{g}^{-1} \cdot \mathrm{h}^{-1}$, specific activity $\left.=35 \mathrm{U} \cdot \mathrm{mg}^{-1}\right)$.

\section{Electrophoresis and glycopeptides analysis by LC-ESI-MS}

Cell-free cultivation broths of the single fed-batch cultivations were analyzed by SDS-PAGE. Cell-free cultivation broth of a wildtype OCH1 strain as well as commercially 
Table 5 Specific productivity $\left(q_{p}\right)$, space-time-yield (STY) and specific enzyme activity at the end of cultivation

\begin{tabular}{llll}
\hline Cultivation & $\mathbf{q}_{\mathbf{p}}\left[\mathbf{U} \cdot \mathbf{g}^{\mathbf{- 1}} \cdot \mathbf{h}^{\mathbf{- 1}}\right]$ & $\mathbf{S T Y}\left[\mathbf{U} \cdot \mathbf{L}^{\mathbf{- 1}} \cdot \mathbf{h}^{\mathbf{- 1}}\right]$ & Spec. activity $\left[\mathbf{U} \cdot \mathbf{m g}^{\mathbf{- 1}}\right]$ \\
\hline DoE1 & 3.30 & 151 & 61.7 \\
DoE2 & 3.46 & 153 & 56.5 \\
DoE3 & 0.03 & 0.45 & 0.21 \\
DoE4 & 0.01 & 1.12 & 0.20 \\
DoE5 & 0.06 & 1.35 & 0.29 \\
DoE6 & 0.56 & 32 & 7.41 \\
DoE7 & 3.49 & 137 & 47.2 \\
DoE8 & 6.19 & 194 & 38.7 \\
DoE9 & 0.96 & 39 & 15.9 \\
DoE10 & 0.07 & 0.66 & 0.54
\end{tabular}

available enzyme preparation from plant were included for comparison (Figure 5).

To identify the different HRP proteins, respective bands were excised (indicated in Figure 5) and glycopeptides were analyzed by HPLC-ESI-MS. In fact, we were able to identify the different HRP preparations (Additional file 2: Table S1). We observed apparent size differences between the 2 HRP A2A preparations from the $\Delta$ och 1 strain and the wildtype $\mathrm{OCH} 1$ strain, which might result from the different degree of glycosylation (lanes 1 and 2), and between HRP A2A and HRP C1A from the wildtype OCH1 strains (lanes 2 and 5; Additional file 2: Table S1).

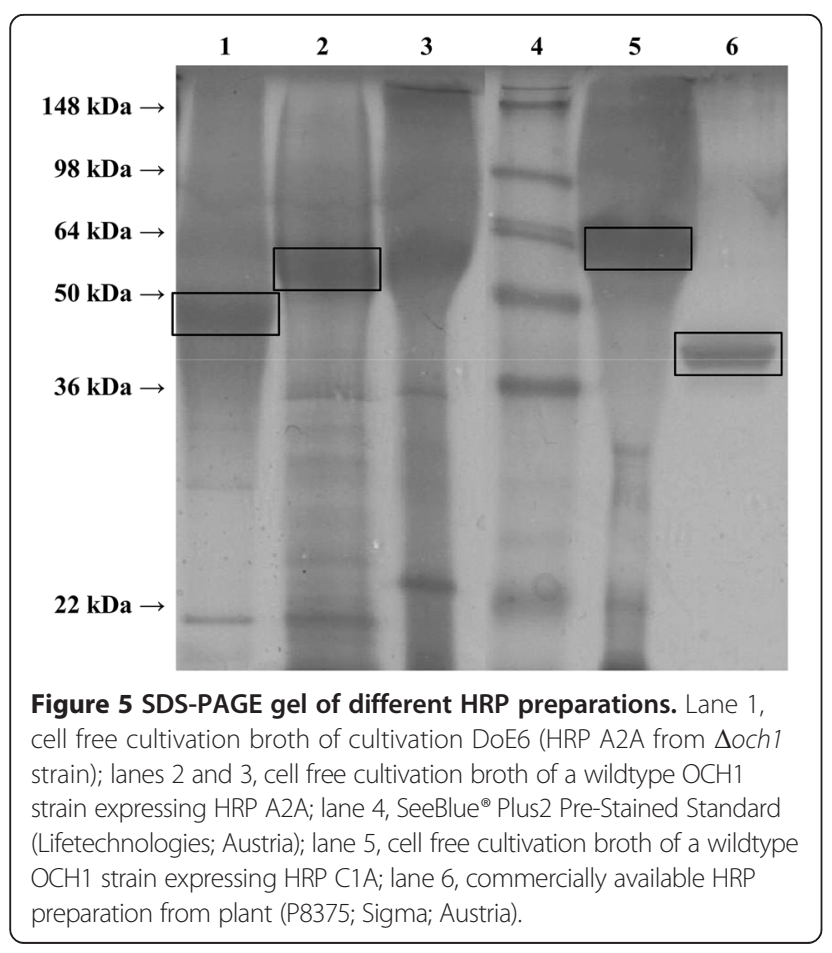

\section{Verification runs at $15^{\circ} \mathrm{C}$}

The results of the DoE revealed a low cultivation temperature to be highly beneficial for productivity and product purity. To check if both responses could be further increased, 2 additional fed-batch cultivations at $15^{\circ} \mathrm{C}$, $\mathrm{pH} 5.0$ and $\mathrm{dO}_{2}$ of $10 \%$ were done. The average $\mathrm{q}_{\mathrm{s}} \mathrm{MeOH}$ adapt was $0.18 \mathrm{mmol} \cdot \mathrm{g}^{-1} \cdot \mathrm{h}^{-1}$, which was comparable to the results at $20^{\circ} \mathrm{C}$ and $25^{\circ} \mathrm{C}$ (Table 2). Apparently, significant changes in $\mathrm{q}_{\mathrm{s}} \mathrm{MeOH}$ adapt of the recombinant $\Delta$ och 1 strain only happened between $25^{\circ} \mathrm{C}$ and $30^{\circ} \mathrm{C}$. Surprisingly, at $15^{\circ} \mathrm{C}$ productivity and product purity were only half compared to $20^{\circ} \mathrm{C}$. We determined a $\mathrm{q}_{\mathrm{p}}$ of 1.50 $\left[\mathrm{U} \cdot \mathrm{g}^{-1} \cdot \mathrm{h}^{-1}\right]$, a STY of $66\left[\mathrm{U} \cdot \mathrm{L}^{-1} \cdot \mathrm{h}^{-1}\right]$ and a specific activity of $23.3\left[\mathrm{U} \cdot \mathrm{mg}^{-1}\right]$ at $15^{\circ} \mathrm{C}$, whereas in $\operatorname{DoE} 2\left(20^{\circ} \mathrm{C}\right.$, pH 5.0, $\left.\mathrm{dO}_{2} 10 \%\right), \mathrm{q}_{\mathrm{p}}$ of $3.46\left[\mathrm{U} \cdot \mathrm{g}^{-1} \cdot \mathrm{h}^{-1}\right]$, a STY of 153 $\left[\mathrm{U} \cdot \mathrm{L}^{-1} \cdot \mathrm{h}^{-1}\right]$ and a specific activity of $56.5\left[\mathrm{U} \cdot \mathrm{mg}^{-1}\right]$ were measured. Thus, we concluded that the highest values for productivity and product purity, which are the main target variables in production processes, might be obtained between $15^{\circ} \mathrm{C}$ and $20^{\circ} \mathrm{C}$, a pH of 5.0 and a $\mathrm{dO}_{2}$ of $10 \%$.

\section{Conclusion}

In the present study we developed a fed-batch bioprocess for a recombinant $P$. pastoris $\Delta o c h 1$ strain. High productivity and product purity were reached when this strain was cultivated at $\mathrm{pH} 5.0, \mathrm{dO}_{2}$ of $10 \%$ and a temperature of $20^{\circ} \mathrm{C}$. At $30^{\circ} \mathrm{C}$ methanol accumulated over time due to apparent changes in cell metabolism. Cell cluster formation, which was accompanied by cell lysis, was dependent on the C-source. To avoid intensive foam formation during glycerol batch and fed-batch, aeration and stirrer speed had to be reduced.

Currently, we are investigating cell cluster formation on other C-sources, like glucose and sorbitol, and analyze the temperature range between $15-20^{\circ} \mathrm{C}$ in more detail to find the true optimum for the recombinant $\Delta o c h 1$ strain. However, the present study already describes a good basis for bioprocess engineers working with glyco-engineered $\Delta o c h 1$ yeast strains.

\section{Additional files}

Additional file 1: Figure S1. Contour plot showing A, specific productivity; B, space-time-yield, and C, specific activity as an indicator for product purity at the end of cultivation in dependence on temperature and $\mathrm{dO}_{2}$.

Additional file 2: Table S1. Results of the protein search with MASCOT (embedded in ProteinScape 3.0, Bruker) for protein identification of the excised bands. Only proteins identified with at least 2 peptides and a protein score higher than 80 were accepted. For searches the SwissProt database was used.

\section{Competing interests}

The authors declare that they have no competing interests. 


\section{Authors' contributions}

CG, AS and MF conducted bioreactor runs and biochemical experiments. SK helped with Malvern Mastersizer analyses. DM and FA conducted mass spectrometry analyses. $\mathrm{CH}$ helped in planning the study. CG, FA and OS analyzed the data. OS planned the study, supervised research and wrote the manuscript. All authors read and approved the final manuscript.

\section{Acknowledgements}

The authors thank the Austrian Science Fund FWF (project: P24861-B19) for financial support and Prof. Anton Glieder (University of Technology, Graz, Austria) for providing the recombinant $P$. pastoris $\Delta$ och 1 strain. Furthermore we want to thank Simona Capone for great assistance in the lab.

\section{Author details}

'Vienna University of Technology, Institute of Chemical Engineering, Research Area Biochemical Engineering, Gumpendorfer Strasse 1a, 1060 Vienna, Austria. ${ }^{2}$ Department of Chemistry, University of Natural Resources and Life Sciences, Vienna, Austria.

\section{Received: 7 September 2014 Accepted: 18 December 2014}

\section{Published online: 08 January 2015}

\section{References}

1. Zhou X, Yu Y, Tao J, Yu L. Production of LYZL6, a novel human c-type lysozyme, in recombinant Pichia pastoris employing high cell density fed-batch fermentation. J Biosci Bioeng. 2014;118:420-5.

2. Ahmad M, Hirz M, Pichler $H$, Schwab H. Protein expression in Pichia pastoris: recent achievements and perspectives for heterologous protein production. Appl Microbiol Biotechnol. 2014;98:5301-17.

3. Weinacker D, Rabert C, Zepeda AB, Figueroa CA, Pessoa A, Farias JG. Applications of recombinant Pichia pastoris in the healthcare industry. Braz J Microbiol. 2013;44:1043-8.

4. Felber M, Pichler $H$, Ruth $C$. Strains and molecular tools for recombinant protein production in Pichia pastoris. Methods Mol Biol. 2014;1152:87-111.

5. Hasslacher M, Schall M, Hayn M, Bona R, Rumbold K, Luckl J, et al. High-leve intracellular expression of hydroxynitrile lyase from the tropical rubber tree Hevea brasiliensis in microbial hosts. Protein Expr Purif. 1997:11:61-71.

6. Werten MW, van den Bosch TJ, Wind RD, Mooibroek H, de Wolf FA. High-yield secretion of recombinant gelatins by Pichia pastoris. Yeast. 1999;15:1087-96.

7. Cereghino GPL, Cereghino JL, Ilgen C, Cregg JM. Production of recombinant proteins in fermenter cultures of the yeast Pichia pastoris. Curr Opin Biotechnol. 2002:13:329-32.

8. Li H, Hui X, Yang S, Hu X, Tang X, Li P, et al. High level expression, efficient purification and bioactivity assay of recombinant human platelet-derived growth factor AA dimer (PDGF-AA) from methylotrophic yeast Pichia pastoris. Protein Expr Purif. 2013;91:221-7.

9. Spadiut O, Capone S, Krainer F, Glieder A, Herwig C. Microbials for the production of monoclonal antibodies and antibody fragments. Trends Biotechnol. 2014;32:54-60.

10. Hamilton SR, Bobrowicz P, Bobrowicz B, Davidson RC, Li HJ, Mitchell T, et al. Production of complex human glycoproteins in yeast. Science. 2003;301:1244-6.

11. Gong B, Cukan M, Fisher R, Li H, Stadheim TA, Gerngross T. Characterization of $\mathrm{N}$-linked glycosylation on recombinant glycoproteins produced in Pichia pastoris using ESI-MS and MALDI-TOF. Methods Mol Biol. 2009;534:213-23.

12. Li H, Miele RG, Mitchell TI, Gerngross TU. N-linked glycan characterization of heterologous proteins. Methods Mol Biol. 2007;389:139-50.

13. Montesino R, Garcia R, Quintero O, Cremata JA. Variation in N-linked oligosaccharide structures on heterologous proteins secreted by the methylotrophic yeast Pichia pastoris. Protein Expr Purif. 1998;14:197-207.

14. Nagasu T, Shimma Y, Nakanishi Y, Kuromitsu J, Iwama K, Nakayama K, et al. Isolation of new temperature-sensitive mutants of Saccharomyces cerevisiae deficient in mannose outer chain elongation. Yeast. 1992;8:535-47.

15. Nakayama K, Nagasu T, Shimma Y, Kuromitsu J, Jigami Y. OCH1 encodes a novel membrane bound mannosyltransferase: outer chain elongation of asparagine-linked oligosaccharides. EMBO J. 1992;11:2511-9.

16. Spadiut O, Rossetti L, Dietzsch C, Herwig C. Purification of a recombinant plant peroxidase produced in Pichia pastoris by a simple 2-step strategy. Protein Expr Purif. 2012:86:89-97.

17. Yang YL, Chang SH, Gong X, Wu J, Liu B. Expression, purification and characterization of low-glycosylation influenza neuraminidase in alpha-1, 6-mannosyltransferase defective Pichia pastoris. Mol Biol Rep. 2012;39:857-64.
18. Wildt S, Gerngross TU. The humanization of N-glycosylation pathways in yeast. Nat Rev Microbiol. 2005:3:119-28.

19. Hamilton SR, Davidson RC, Sethuraman N, Nett JH, Jiang Y, Rios S, et al. Humanization of yeast to produce complex terminally sialylated glycoproteins. Science. 2006;313:1441-3.

20. Hamilton SR, Gerngross TU. Glycosylation engineering in yeast: the advent of fully humanized yeast. Curr Opin Biotechnol. 2007;18:387-92.

21. De Pourcq K, De Schutter K, Callewaert N. Engineering of glycosylation in yeast and other fungi: current state and perspectives. Appl Microbiol Biotechnol. 2010;87:1617-31.

22. Vervecken W, Kaigorodov V, Callewaert N, Geysens S, De Vusser K, Contreras R. In vivo synthesis of mammalian-like, hybrid-type $\mathrm{N}$-glycans in Pichia pastoris. Appl Environ Microbiol. 2004:70:2639-46.

23. Krainer FW, Gmeiner C, Neutsch L, Windwarder M, Pletzenauer R, Herwig C, et al. Knockout of an endogenous mannosyltransferase increases the homogeneity of glycoproteins produced in Pichia pastoris. Sci Rep. 2013;3:3279.

24. Spadiut $\mathrm{O}$, Herwig C. Production and purification of the multifunctional enzyme horseradish peroxidase: a review. Pharm Bioproc. 2013;1:283-95.

25. Dietzsch C, Spadiut O, Herwig C. A fast approach to determine a fed batch feeding profile for recombinant Pichia pastoris strains. Microb Cell Fact. 2011;10:85.

26. Dietzsch C, Spadiut O, Herwig C. A dynamic method based on the specific substrate uptake rate to set up a feeding strategy for Pichia pastoris. Microb Cell Fact. 2011;10:14

27. Krainer FW, Pletzenauer R, Rossetti L, Herwig C, Glieder A, Spadiut O. Purification and basic biochemical characterization of 19 recombinant plant peroxidase isoenzymes produced in Pichia pastoris. Protein Expr Purif. 2013;95C:104-12

28. Jeong GM, Lee YJ, Kim YS, Jeong KJ. High-level production of Fc-fused kringle domain in Pichia pastoris. J Ind Microbiol Biotechnol. 2014;41:989-96.

29. Peng Z, Wang A, Feng Q, Wang Z, Ivanova IV, He X, et al. High-level expression, purification and characterisation of porcine beta-defensin 2 in Pichia pastoris and its potential as a cost-efficient growth promoter in porcine feed. Appl Microbiol Biotechnol. 2014;98:5487-97.

30. Berdichevsky M, d'Anjou M, Mallem MR, Shaikh SS, Potgieter TI. Improved production of monoclonal antibodies through oxygen-limited cultivation of glycoengineered yeast. J Biotechnol. 2011;155:217-24.

31. Dragosits M, Frascotti G, Bernard-Granger L, Vazquez F, Giuliani M, Baumann $K$, et al. Influence of growth temperature on the production of antibody Fab fragments in different microbes: a host comparative analysis. Biotechnol Prog. 2011;27:38-46.

32. Potgieter TI, Cukan M, Drummond JE, Houston-Cummings NR, Jiang Y, Li F, et al. Production of monoclonal antibodies by glycoengineered Pichia pastoris. J Biotechnol. 2009;139:318-25.

33. Minning S, Serrano A, Ferrer P, Sola C, Schmid RD, Valero F. Optimization of the high-level production of Rhizopus oryzae lipase in Pichia pastoris. J Biotechnol. 2001:86:59-70.

34. Krainer FW, Dietzsch C, Hajek T, Herwig C, Spadiut O, Glieder A. Recombinant protein expression in Pichia pastoris strains with an engineered methanol utilization pathway. Microb Cell Fact. 2012;11:22.

35. Reay DS, Nedwell DB, Priddle J, Ellis-Evans JC. Temperature dependence of inorganic nitrogen uptake: reduced affinity for nitrate at suboptimal temperatures in both algae and bacteria. Appl Environ Microbiol. 1999;65:2577-84.

36. Pomeroy LR, Wiebe WJ. Temperature and substrates as interactive limiting factors for marine heterotrophic bacteria. Aquat Microb Ecol. 2001;23:187-204.

37. Nedwell DB. Effect of low temperature on microbial growth: lowered affinity for substrates limits growth at low temperature. Fems Microbiol Ecol. 1999:30:101-11.

38. Rambourg A, Clermont Y, Ovtracht L, Kepes F. Three-dimensional structure of tubular networks, presumably Golgi in nature, in various yeast strains: a comparative study. Anat Rec. 1995;243:283-93. 